\title{
Accumulation and biomass partition and nutrients per tropical ornamental plants grown in Ribeira Valley region ${ }^{(1)}$
}

\author{
LEANDRO JOSÉ GRAVA DE GODOY(2)*; MARCELO VIEIRA FERRAZ ${ }^{(2)}$; \\ LUCAS DA SILVA ${ }^{(2)}$; MARCOS VIEIRA FERRAZ(3)
}

\begin{abstract}
For many ornamental plants there are no fertilization tables in Brazil and growers use, inappropriately, the same fertilizing for different species of ornamental plants. A first step is to know the nutrient uptake by these plants. The objective of this study was to determine the concentration and to characterize the accumulation of nutrients of the main tropical ornamental plants grown in the Ribeira Valley region, São Paulo state, Brazil: Clusia fluminensis, Dracaena marginata, Dypsis lutescens, Gardenia jasminoides, Ixora coccinea, Ligustrum sinense, Murraya paniculata, Podocarpus macrophyllus, Rhapis excelsa e Viburnum prunifolium. The plants were donated by local farmers and after sorting, these were divided into roots, stems and leaves, and, subsequently, washed, dried and was determined their concentration of nutrients. The experimental design was randomized using four repetitions and the species of ornamental plants were considered as treatments. The results were submitted to analysis of variance and compared by Scott-Knott test (5\%). For the macronutrient, the greater accumulation of $\mathrm{N}$ was in Podocarpus macrophyllus. The Clusia fluminensis tree had the highest calcium and magnesium accumulations. The largest amounts of $\mathrm{P}$ and $\mathrm{S}$ were accumulated in Rhapis excelsa and Podocarpus macrophyllus. The greatest accumulation of $\mathrm{K}$ was in Rhapis excelsa, Dracaena marginata, Podocarpus macrophyllus, Murraya paniculata and Ixora coccinea. Smaller amounts of macronutrients were accumulated in Dypsis lutescens and Viburnum prunifolium. As for the macronutrients, the largest accumulation of $\mathrm{Cu}$ was observed in broad leaf Rhapis excelsa. Clusia fluminensis tree and Dracaena marginata accumulated the largest amounts of Mn. Regarding the Zn, Rhapis excelsa, Dracaena marginata and Ligustrum sinense were plants with higher accumulation. Smaller amounts of B were accumulated in Viburnum prunifolium, Dracaena marginata and Dypsis lutescens. Ligustrum sinense, Dypsis lutescens and Ixora coccinea accumulated lower amounts of $\mathrm{Fe}$ in relation to others. The accumulation of nutrients by ornamental plants is very different between species and this information should be used to adjust fertilizer recommendations. Ornamental plants were grouped as demand and NPK ratio, to assist in the management of fertilizer.
\end{abstract}

Keywords: fertility, floriculture, nutrition, landscape, fertilizing.

\section{RESUMO}

Acúmulo e partição da biomassa e dos nutrientes em plantas ornamentais tropicais produzidas na região do Vale do Ribeira

Para muitas plantas ornamentais não há tabelas de adubação no Brasil e produtores utilizam, de forma inadequada, a mesma adubação para diferentes espécies de plantas ornamentais. Um primeiro passo é conhecer a extração de nutrientes por estas plantas. Objetivou-se com o trabalho determinar a concentração e caracterizar o acúmulo de nutrientes nas principais plantas ornamentais cultivadas na região do Vale do Ribeira, São Paulo: Clusia fluminensis (clusia), Dracaena marginata (dracena-tricolor), Dypsis lutescens (areca-bambú), Gardenia jasminoides (gardênia), Ixora coccinea (ixóra vermelha), Ligustrum sinense (ligustro), Murraya paniculata (murta-de-cheiro), Podocarpus macrophyllus (pinheiro-budista), Rhapis excelsa (palmeira-rápis) e Viburnum prunifolium (viburno). As plantas foram doadas por produtores da região e após classificação, estas foram divididas em raiz, caule e folhas, sendo, na sequência, lavadas, secas e determinada a concentração de nutrientes. O delineamento experimental foi inteiramente casualizado utilizando-se de quatro repetições e as espécies das plantas ornamentais foram consideradas como tratamentos. Os resultados foram submetidos à análise de variância e comparados pelo teste de Scott-Knott (5\%). O maior acúmulo de N foi no Podocarpus macrophyllus. A Clusia fluminensis apresentou os maiores acúmulos de cálcio e magnésio. As maiores quantidades de $\mathrm{P}$ e $\mathrm{S}$ foram acumuladas na Rhapis excelsa e no Podocarpus macrophyllus. O maior acúmulo de $\mathrm{K}$ foi na Rhapis excelsa, Dracaena marginata, Podocarpus macrophyllus, Murraya paniculata e Ixora coccinea. As menores quantidades dos macronutrientes foram acumuladas na Dypsis lutescens e no Viburnum prunifolium. Já para os micronutrientes o maior acúmulo de $\mathrm{Cu}$ foi observado na Rhapis excelsa. A Clusia fluminensis e a Dracaena marginata acumularam as maiores quantidades de Mn. Em relação ao Zn, Rhapis excelsa, Dracaena marginata e Ligustrum sinense foram as plantas com maior acúmulo. As menores quantidades de B foram acumuladas no Viburnum prunifolium, Dracaena marginata e Dypsis lutescens. Ligustrum sinense, Dypsis lutescens e Ixora coccinea acumularam menores quantidades de Fe em relação às demais. $\mathrm{O}$ acúmulo de nutrientes pelas plantas ornamentais é bastante diferenciado entre as espécies e esta informação deve ser utilizada para ajustar as recomendações de adubação. As plantas ornamentais foram agrupadas quanto à demanda e a relação NPK, para auxiliar no manejo da adubação. Palavras-chave: fertilidade, floricultura, nutrição, paisagismo, adubação.

\footnotetext{
(1) Received in 19/08/2016 and accepted in 26/10/2016

(2) Universidade Estadual Paulista (UNESP), Campus de Registro, Registro-SP, Brazil. *Corresponding author: legodoy@registro.unesp.br

(3) Universidade Estadual Paulista (UNESP), Faculdade de Ciências Agronômicas, Departamento de Horticultura, Botucatu-SP, Brasil.
} 


\section{INTRODUCTION}

The production and the market of flowers and ornamental plants are in the growth stage. Evaluation made by IBRAFLOR (2015) foresees that the increase in the national market flowers will be $8 \%$ in 2015 . This is due to the country extraordinary production conditions, provided with soil and climate diversity, that enable the cultivation of an infinite number of plant species of flowers and ornamental plants, granting opportunities to open space and to enter into the international market to the Brazilian products (VIEIRA et al., 2015).

Currently floriculture is distributed virtually throughout the country, highlighting the states of Santa Catarina, Rio Grande do Sul, Paraná, Minas Gerais, Rio de Janeiro, Goiás, Distrito Federal and in the northeastern areas covered by Ceará, Pernambuco, Alagoas and Bahia (JUNQUEIRA and PEETZ, 2005).

The area currently occupied by the floriculture is 14,992 hectares. Throughout Brazil there are 8,248 producers with growth possibilities. It has being produced 350 species, 3,000 varieties with a consumption of $\mathrm{R} \$ 26.68$ / inhabitant (IBRAFLOR, 2015).

The State of São Paulo, in addition to being the largest producer, is also the largest exporter of floriculture products. The Ribeira Valley, because of the location and environmental conditions of the region, stands out for the production of plants for use in landscaping projects. The hot and humid climate with annual rainfall from 1500 to 2000 $\mathrm{mm}$ and relative humidity between $75-95 \%$ has provided the development of the cultivation of flowers and tropical plants. The cultivation of ornamental plants is in increasing process of expansion, and it is an activity of great economic and social importance for the region, and the opportunity for development of family farming which occupies small area, fixes manpower in the field, diversifies production and generates income (LINS and COELHO, 2004).

In order that occurs an increase in production, both in quality and quantity, more studies are necessary in the production chain of these plants. Thus perform nutrient accumulation curve is one of the ways of monitoring the need for particular nutrient throughout the cycle of a culture in each phenological stage. These activities reduces the risk of application of excessive doses of fertilizers as well as provide doses below the minimum required by the plant to achieve desired productivity goals without quality losses (BECKMANN-CAVALCANTE et al., 2010).
For many ornamental plants there are no fertilization tables in Brazil and growers use, inappropriately, the same fertilizing for different species of ornamental plants. A first step is to know the accumulation of nutrients by the plants that can serve as a basis for fertilization.

Many farmers grow several species of ornamental plants. Despite the difference of demand for nutrients between the species of ornamental plants, through likelihood tests can group certain species, thus facilitating the fertilization management.

The objective of this study was to determine the concentration and to characterize the accumulation of nutrients of the main ornamental plants grown in the Ribeira Valley region and group them according to the demand for nutrients to assist in recommendation of fertilization.

\section{MATERIAL E METHODS}

The experiment was conducted in Registro city, São Paulo, Brazil. The plants were supplied by producers from the Ribeira Valley region, associated with AFLOVAR (Ribeira Valley Flower and Plants Producers Association). The plants were grown in the field, but for marketing they are transplanted into pots.

The experimental design was randomized using four repetitions. The treatments consisted of ten species of ornamental plants. The species were suggested by AFLOVAR: Clusia fluminensis (abaneiro tree), Dracaena marginata (pleomele), Dypsis lutescens (bamboo palm), Gardenia jasminoides (gardenia), Ixora coccinea (jungle geranium), Ligustrum sinense (Chinese privet), Murraya paniculata (orange jasmine), Podocarpus macrophyllus (Buddhist pine), Rhapis excelsa (lady palm) e Viburnum prunifolium (blackhaw).

It was collected four pots of each kind of species for the experiment, in marketing point, which was carried out in the characterization of each plant used in the experiment. The number of plants per pot was counted and plant height was determined using a measuring tape, from the substrate surface to the insertion of the last leaf. It was considered the highest stem for those plants with more than one stem, of which the diameter was measured using caliper rule. Pots with more than one stem was measured the diameter of the largest and smallest stem. The plants were separated into shoots and roots, and the parts were weighed to determine the fresh matter. The average characteristics of the plants are showed in Table 1. 
Table 1. Characteristics averages of four plants of each species collected in grower at Ribeira Valley region, SP, to determine the nutrient extraction.

\begin{tabular}{|c|c|c|c|c|c|c|}
\hline $\begin{array}{l}\text { Species of } \\
\text { ornamental } \\
\text { plants }\end{array}$ & $\begin{array}{c}\text { Number of } \\
\text { plants per pot }\end{array}$ & $\begin{array}{c}\text { Stem } \\
\text { diameter }\end{array}$ & $\begin{array}{l}\text { Plant } \\
\text { height }\end{array}$ & $\begin{array}{l}\text { Fresh matter } \\
\text { of roots }\end{array}$ & $\begin{array}{c}\text { Fresh matter } \\
\text { of the aerial } \\
\text { part }\end{array}$ & $\begin{array}{l}\text { Total fresh } \\
\text { matter }\end{array}$ \\
\hline & & $\mathbf{m m}$ & $\mathbf{m}$ & -------------. & --------- g ------- & ---------- \\
\hline Ixora coccinea & 2 & 17.9 & 0.81 & 103 & 530 & 645 \\
\hline $\begin{array}{c}\text { Gardenia } \\
\text { jasminoides }\end{array}$ & 1 & 16.4 & 0.49 & 128 & 414 & 580 \\
\hline Rhapis excelsa & 1 & 23.8 & 1.00 & 294 & 644 & 979 \\
\hline $\begin{array}{l}\text { Podocarpus } \\
\text { macrophyllus }\end{array}$ & 2 & 15.7 & 1.41 & 205 & 964 & 1171 \\
\hline $\begin{array}{l}\text { Ligustrum } \\
\text { sinense }\end{array}$ & 2 & 15.6 & 0.78 & 125 & 394 & 528 \\
\hline $\begin{array}{c}\text { Murraya } \\
\text { paniculata }\end{array}$ & 2 & 16.8 & 1.10 & 121 & 370 & 500 \\
\hline $\begin{array}{c}\text { Clusia } \\
\text { fluminensis }\end{array}$ & 1 & 21.4 & 0.71 & 250 & 1095 & 1384 \\
\hline $\begin{array}{c}\text { Viburnum } \\
\text { prunifolium }\end{array}$ & 1 & 11.9 & 0.45 & 89 & 255 & 367 \\
\hline $\begin{array}{l}\text { Dracaena } \\
\text { marginata }\end{array}$ & 2 & 19.3 & 1.20 & 214 & 263 & 448 \\
\hline Dypsis lutescens & 5 & 36.3 & 1.47 & - & - & 339 \\
\hline
\end{tabular}

The substrates used in pots of each species were separated, identified and a sample was sent to determine chemical characteristics for fertility purposes, according Raij et al. (2001), and the results are shown in Table 2. 
Table 2. Chemical characteristics of the soil where the species of ornamental plants were grown, collected in grower from Ribeira Valley region, SP.

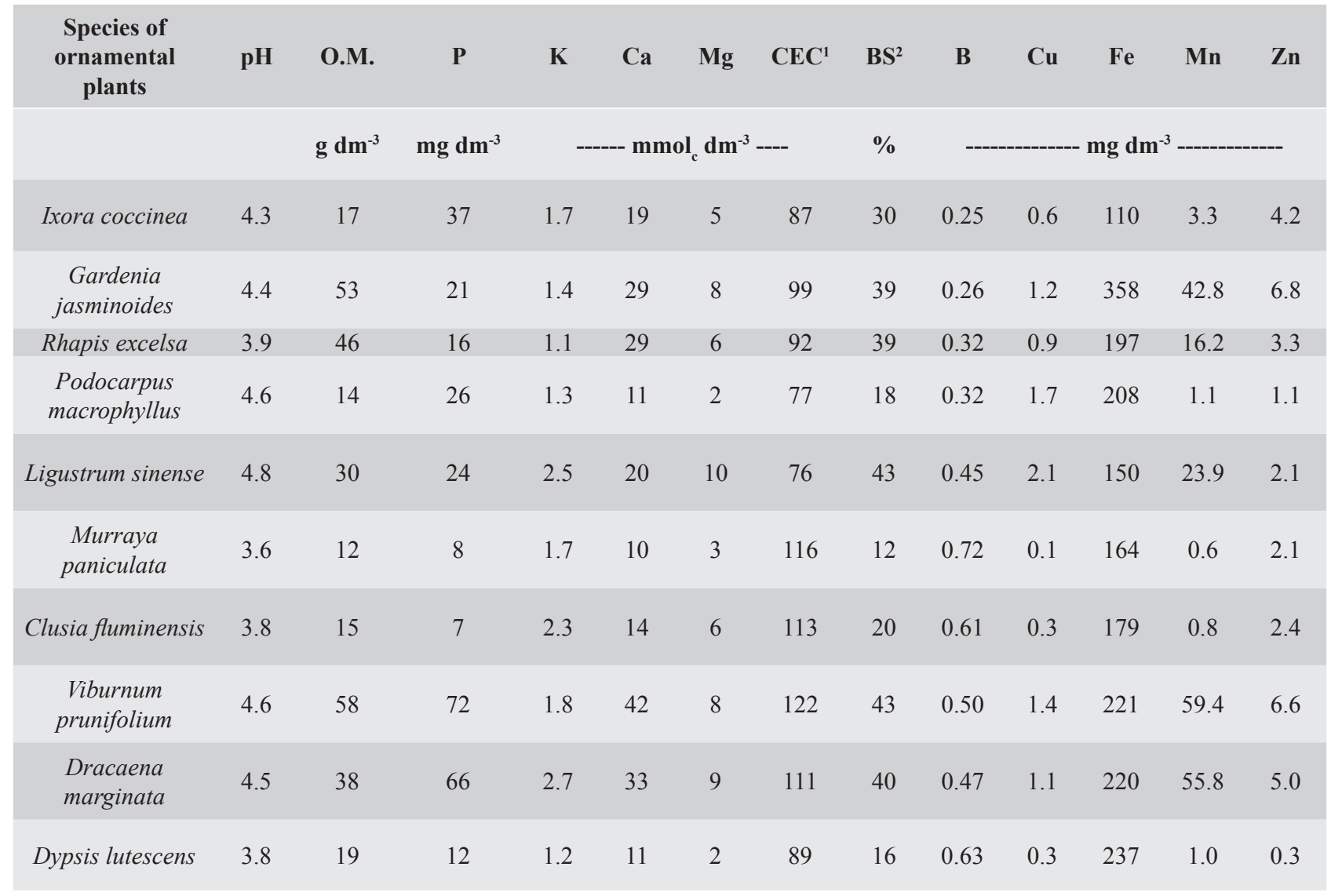

${ }^{1}$ Cation exchange capacity of soil; ${ }^{2}$ Soil base saturation

The plants of each species were washed and separated into leaves, stems and roots, placed in paper bags and brought into circulation oven with replaced and forced air temperature of $65^{\circ} \mathrm{C}$ for at least 72 hours.

The leaves, stems and roots were weighed after drying the material to obtain dry mass and then ground in a Willey mill type. After ground, samples of all plants were sent to a laboratory certified with ISO / IEC 17025 and accredited into the Laboratory Program of the Brazilian Society of Soil Science to determine the concentration of nutrients, according to the methodology of Malavolta et al. (1997).

The amount of nutrients extracted by the plant was calculated by the product of dry matter and concentration obtained in each part. The total amount of nutrient extracted by plants was calculated by summing the amount of nutrient extracted from the leaves, stems and roots. It was opted for the fractionation of plant parts and then get the full extraction by the plant by the difficulty of working with the whole plant, due to the larger of some species, and for the sake of accuracy in determining the nutrient content, as this differs from the plant parts.

The results were submitted to analysis of variance by $F$ test, and calculated the probability of $F$ calculated to be greater than the F tabulated, and the averages compared by Scott-Knott test at 5\% probability using the SISVAR software v. 5.0. The Scott-Knott test (1974) was chosen because it is a comparison experiment between species of ornamental plants and for being a likelihood ratio test to partition levels treatments in well-defined groups and do not have the ambiguity of others.

\section{RESULTS AND DISCUSSION}

Podocarpus macrophyllus and Rhapis excelsa were the plants that accumulated more total dry biomass (Table 3 ), that due to its size (Table 1) and the plants that less accumulated total biomass were Dypsis lutescens and Viburnum prunifolium (Table 3). 
Table 3. Summary of the analysis of variance and the averages of total dry matter and the parts of ornamental plants.

\begin{tabular}{|c|c|c|c|c|}
\hline Factor of variation & \multicolumn{4}{|c|}{ Dry matter } \\
\hline & \multicolumn{4}{|c|}{ - } \\
\hline Specie (S) & \multicolumn{4}{|c|}{0,001} \\
\hline Part of the plant (P) & \multicolumn{4}{|c|}{0,001} \\
\hline $\mathbf{S} \times \mathbf{P}$ & \multicolumn{4}{|c|}{0,001} \\
\hline $\mathrm{CV}, \%$ & \multicolumn{4}{|c|}{31,51} \\
\hline \multirow{2}{*}{ Species of ornamental plants } & \multicolumn{4}{|c|}{ 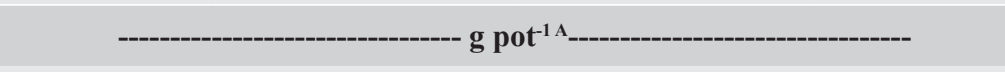 } \\
\hline & Leaf & Stem & Root & Total \\
\hline Ixora coccinea & $87.50 \mathrm{Ca}^{\mathrm{B}}$ & $123.20 \mathrm{aA}$ & $56.00 \mathrm{aA}$ & $266.70 \mathrm{~b}$ \\
\hline Gardenia jasminoides & $57.50 \mathrm{cA}$ & $111.50 \mathrm{aA}$ & $50.25 \mathrm{aA}$ & $219.25 \mathrm{c}$ \\
\hline Rhapis excelsa & $135.50 \mathrm{bA}$ & $170.00 \mathrm{aA}$ & $125.75 \mathrm{aA}$ & $431.25 \mathrm{a}$ \\
\hline Podocarpus macrophyllus & $228.75 \mathrm{aA}$ & $145.00 \mathrm{aB}$ & $74.25 \mathrm{aC}$ & $448.00 \mathrm{a}$ \\
\hline Ligustrum sinense & $56.00 \mathrm{cB}$ & $165.00 \mathrm{aA}$ & $59.50 \mathrm{aB}$ & $280.50 \mathrm{~b}$ \\
\hline Murraya paniculata & $49.50 \mathrm{cB}$ & $156.00 \mathrm{aA}$ & $58.50 \mathrm{aB}$ & $264.00 \mathrm{~b}$ \\
\hline Clusia fluminensis & $133.00 \mathrm{bA}$ & $131.50 \mathrm{aA}$ & $58.50 \mathrm{aB}$ & $323.00 \mathrm{~b}$ \\
\hline Viburnum prunifolium & $29.00 \mathrm{cA}$ & $34.75 \mathrm{bA}$ & $42.50 \mathrm{aA}$ & $106.25 \mathrm{~d}$ \\
\hline Dracaena marginata & $47.75 \mathrm{cA}$ & $63.00 \mathrm{bA}$ & $57.75 \mathrm{aA}$ & $168.50 \mathrm{c}$ \\
\hline Dypsis lutescens & $31.50 \mathrm{cA}$ & $29.00 \mathrm{bA}$ & $35.00 \mathrm{aA}$ & $95.50 \mathrm{~d}$ \\
\hline
\end{tabular}

${ }^{\mathrm{A}}$ The average results were expressed in grams per pot rather than grams per plant, depending on the species because there are more than one plant per pot, as a constituting; ${ }^{\mathrm{B}}$ Averages followed by the same lower case letter do not differ between species of plants and averages followed by the letters do not differ between the organs of the species by Scott-Knott test, at 5\% probability. The total dry weight was compared only among species.

The higher accumulation of biomass in the roots was observed in Rhapis excelsa, in relation to other species. The plants that had lower dry matter accumulation in their stems were Dracaena marginata, Viburnum prunifolium and Dypsis lutescens (Table 3). The Podocarpus macrophyllus was the species with the highest amount of dry weight in the leaves, differing from Clusia fluminensis and Raphis excelsa that had an average accumulation, followed by other species (Table 3). This can be explained by the large amount of Podocarpus macrophyllus leaves, that although are small, they are arranged throughout the plant.

Ligustrum sinense and Murraya paniculata accumulated more biomass in the stem, in relation to their leaves and roots (Table 3). Clusia fluminensis accumulated more biomass in the leaves and stem over the roots. The Podocarpus macrophyllus accumulated higher amount of dry matter in leaves, then stems and then roots. While other plants have a biomass equal partition between leaves, stems and roots (Table 3 ).

The nitrogen content in the leaves differed among species, and the Ligustrum sinense showed the highest concentration of nutrients in their leaves, primarily due to the plant structure and its many leaves. Followed by Murraya paniculata and Dracaena marginata. The other species have equivalent nitrogen content among them (Table 4). 
Table 4. Summary of the analysis of variance and means of macronutrient concentration in leaves of ornamental plants.

\begin{tabular}{|c|c|c|c|c|c|c|}
\hline \multirow[b]{2}{*}{$\begin{array}{l}\text { Factor of } \\
\text { variation }\end{array}$} & \multicolumn{6}{|c|}{ Macronutrient concentration in leaves } \\
\hline & $\mathbf{N}$ & $\mathbf{P}$ & $\mathbf{K}$ & $\mathrm{Ca}$ & Mg & $\mathbf{S}$ \\
\hline & \multicolumn{6}{|c|}{ - } \\
\hline $\begin{array}{l}\text { Species of } \\
\text { ornamental } \\
\text { plants }\end{array}$ & $<0.001$ & $<0.001$ & $<0.001$ & $<0.001$ & $<0.001$ & $<0.001$ \\
\hline CV \% & 13.25 & 20.28 & 18.85 & 17.17 & 13.91 & 20.62 \\
\hline $\begin{array}{c}\text { Species of } \\
\text { ornamental } \\
\text { plants }\end{array}$ & \multicolumn{6}{|c|}{ - } \\
\hline Ixora coccinea & $11.95 \mathrm{c}^{\mathrm{A}}$ & $1.02 \mathrm{~b}$ & $14.05 \mathrm{~b}$ & $5.57 \mathrm{c}$ & $4.07 \mathrm{~b}$ & $2.25 \mathrm{a}$ \\
\hline $\begin{array}{c}\text { Gardenia } \\
\text { jasminoides }\end{array}$ & $13.97 \mathrm{c}$ & $1.32 \mathrm{~b}$ & $9.77 \mathrm{c}$ & $11.30 \mathrm{~b}$ & $3.37 \mathrm{c}$ & $1.62 \mathrm{~b}$ \\
\hline Rhapis excelsa & $12.97 \mathrm{c}$ & $1.10 \mathrm{~b}$ & $13.97 \mathrm{~b}$ & $2.20 \mathrm{~d}$ & $1.17 \mathrm{e}$ & $1.65 \mathrm{~b}$ \\
\hline $\begin{array}{l}\text { Podocarpus } \\
\text { macrophyllus }\end{array}$ & $14.25 \mathrm{c}$ & $1.42 \mathrm{a}$ & $7.50 \mathrm{c}$ & $10.25 \mathrm{~b}$ & $2.87 \mathrm{c}$ & $2.35 \mathrm{a}$ \\
\hline $\begin{array}{l}\text { Ligustrum } \\
\text { sinense }\end{array}$ & $24.35 \mathrm{a}$ & $1.70 \mathrm{a}$ & $7.75 \mathrm{c}$ & $5.00 \mathrm{c}$ & $2.35 \mathrm{~d}$ & $1.92 \mathrm{~b}$ \\
\hline $\begin{array}{l}\text { Murraya } \\
\text { paniculata }\end{array}$ & $18.42 \mathrm{~b}$ & $1.37 \mathrm{a}$ & $21.40 \mathrm{a}$ & $10.72 \mathrm{~b}$ & $2.65 \mathrm{~d}$ & $2.22 \mathrm{a}$ \\
\hline $\begin{array}{c}\text { Clusia } \\
\text { fluminensis }\end{array}$ & $12.37 \mathrm{c}$ & $1.07 \mathrm{~b}$ & $4.80 \mathrm{c}$ & $22.70 \mathrm{a}$ & $5.02 \mathrm{a}$ & $1.79 \mathrm{~b}$ \\
\hline $\begin{array}{l}\text { Viburnum } \\
\text { prunifolium }\end{array}$ & $13.47 \mathrm{c}$ & $1.22 \mathrm{~b}$ & $21.32 \mathrm{a}$ & $10.82 \mathrm{~b}$ & $3.15 \mathrm{c}$ & $0.80 \mathrm{c}$ \\
\hline $\begin{array}{l}\text { Dracaena } \\
\text { marginata }\end{array}$ & $18.77 \mathrm{~b}$ & $1.12 \mathrm{~b}$ & $20.20 \mathrm{a}$ & $20.60 \mathrm{a}$ & $5.30 \mathrm{a}$ & $1.60 \mathrm{~b}$ \\
\hline $\begin{array}{l}\text { Dypsis } \\
\text { lutescens }\end{array}$ & $14.10 \mathrm{c}$ & $0.75 \mathrm{~b}$ & $8.37 \mathrm{c}$ & $9.40 \mathrm{~b}$ & $2.27 \mathrm{~d}$ & $1.80 \mathrm{~b}$ \\
\hline
\end{tabular}

${ }^{\text {A }}$ The averages followed by the same lower case letter do not differ among plant species by Scott-Knott test, at $5 \%$ probability.

Ligustrum sinense, Podocarpus macrophyllus and Murraya paniculata were the species with the highest content of $\mathrm{P}$ in the leaves, followed by the others (Table 4). In Ixora coccinea, P deficiency, in combination with $\mathrm{K}$ deficiency, results in diffuse reddish spotting on the oldest leaves (BROSCHAT, 2008).

Viburnum prunifolium and Dracaena marginata showed the highest concentration for $\mathrm{K}$ (Table 4). According to Tombolato et al. (1997) a higher value was shown than the adequate for leaves of hibiscus $15-30 \mathrm{~g} \mathrm{~kg}^{-1}$, differing from Rhapis excelsa and Ixora coccinea which had an average leaf content among plants followed by other species with lower content of this element.

Rhapis excelsa presented lower $\mathrm{Ca}$ content in the leaf among the species, being ten times lower than that observed in Clusia fluminensis and Dracaena marginata. The foliar calcium considered suitable for Rhapis excelsa is from 4 to $10 \mathrm{~g} \mathrm{~kg}^{-1}$ (UCHIDA, 2000). The leaf nutrient content of healthy plants of Rhalpis excelsa with market quality standards were of 2.69 to $4.04 \mathrm{~g} \mathrm{~kg}^{-1} \mathrm{Ca}$ (ALVES et al., 2010). Gardenia jasminoides, Murraya paniculata,
Viburnum prunifolium and Dypsis lutescens showed foliar $\mathrm{Ca}$ equivalent. Ixora coccinea and Ligustrum sinense had intermediate levels in Ca concentration (Table 4).

The $\mathrm{Mg}$ content in the leaves was the most differed between species, occurring five groupings, the species with the highest concentration were the Dracaena marginata and Clusia fluminensis followed by Ixora coccinea, Podocarpus macrophyllus and Gardenia jasminoides, and other species at both levels groups lower (Table 4). For the Dracaena marginata and Clusia fluminensis the high content is mainly due to the high amount of $\mathrm{Mg}$ in the soil they were grown (Table 2). The smallest magnesium concentration on leaf was observed in Rhapis excelsa. Magnesium deficiency in palms is accentuated by high levels of $\mathrm{N}$ and $\mathrm{K}$ in landscape soils (BROSCHAT, 2014a).

The $\mathrm{S}$ content in the leaves was higher in Ixora coccinea, Podocarpus macrophyllus and Murraya paniculata. Viburnum prunifolium showed the lowest concentration among the plants, where there was no difference in the concentration of this element (Table 4). 
The B content in leaves differed according to species where Ixora coccinea, Ligustrum sinense and Viburnum prunifolium showed the highest concentrations. The species that showed lower leaf concentration of B was Rhapis excelsa (Table 5). But the B levels are not worrisome because all the plants were cultivated in soils that had medium to high levels of B (Table 2). Because palms have a single apical meristem, deficiencies of B can be fatal (BROSCHAT, 2009).
Gardenia jasminoides was a plant that had higher Fe content in its leaves differing from all other species. Murraya paniculata, Dracaena marginata and Dypsis lutescens showed slightly lower level for this element (Table 5). According to Broschat (2008) iron deficiency occurs in alkaline soils, which does not fit the soil profiles studied.

Table 5. Summary of the analysis of variance and means of micronutrient content in the leaves of ornamental plants.

\begin{tabular}{|c|c|c|c|c|c|}
\hline \multirow[b]{2}{*}{ Factor of variation } & \multicolumn{5}{|c|}{ Micronutrient concentration in leaves } \\
\hline & B & $\mathbf{F e}$ & $\mathrm{Cu}$ & Mn & Zn \\
\hline & \multicolumn{5}{|c|}{------------------------------- Pr > Fc -------------------------- } \\
\hline Species of ornamental plants & $<0.001$ & $<0.001$ & $<0.001$ & $<0.001$ & $<0.001$ \\
\hline CV \% & 15.59 & 20.34 & 16.08 & 44.22 & 18.42 \\
\hline Species of ornamental plants & \multicolumn{5}{|c|}{--------------------------- $\mathrm{mg} \mathrm{kg}^{-1}$-------------------------- } \\
\hline Ixora coccinea & $38.01 \mathrm{a}^{\mathrm{A}}$ & $148.25 \mathrm{~d}$ & $11.25 \mathrm{a}$ & $19.50 \mathrm{~d}$ & $35.25 \mathrm{~b}$ \\
\hline Gardenia jasminoides & $31.52 \mathrm{~b}$ & $571.75 \mathrm{a}$ & $7.00 \mathrm{c}$ & $43.25 \mathrm{~d}$ & $16.50 \mathrm{c}$ \\
\hline Rhapis excelsa & $11.55 \mathrm{~d}$ & $254.50 \mathrm{c}$ & $6.50 \mathrm{c}$ & $95.50 \mathrm{~b}$ & $9.25 \mathrm{~d}$ \\
\hline Podocarpus macrophyllus & $19.25 \mathrm{c}$ & $154,50 \mathrm{~d}$ & $4.75 \mathrm{~d}$ & $26.50 \mathrm{~d}$ & $12.25 \mathrm{~d}$ \\
\hline Ligustrum sinense & $45.90 \mathrm{a}$ & $205.75 \mathrm{~d}$ & $8.25 \mathrm{~b}$ & $165.75 \mathrm{~b}$ & $38.75 \mathrm{a}$ \\
\hline Murraya paniculata & $26.75 \mathrm{~b}$ & $371.50 \mathrm{~b}$ & $6.50 \mathrm{c}$ & $61.50 \mathrm{~d}$ & $11.00 \mathrm{~d}$ \\
\hline Clusia fluminensis & $25.55 \mathrm{~b}$ & $164.75 \mathrm{~d}$ & $6.50 \mathrm{c}$ & $148.00 \mathrm{~b}$ & $18.00 \mathrm{c}$ \\
\hline Viburnum prunifolium & $41.00 \mathrm{a}$ & $281.25 \mathrm{c}$ & $3.37 \mathrm{~d}$ & $91.25 \mathrm{~b}$ & $45.00 \mathrm{a}$ \\
\hline Dracaena marginata & $29.72 \mathrm{~b}$ & $380.00 \mathrm{~b}$ & $5.12 \mathrm{~d}$ & $531.25 \mathrm{a}$ & $28.00 \mathrm{~b}$ \\
\hline Dypsis lutescens & $27.77 \mathrm{~b}$ & $348.75 \mathrm{~b}$ & $7.37 \mathrm{c}$ & $126.25 \mathrm{~b}$ & $31.25 \mathrm{~b}$ \\
\hline
\end{tabular}

A The averages followed by the same lower case letter do not differ among plant species by Scott-Knott test, at 5\% probability.

The species with the highest concentration of $\mathrm{Cu}$ in the leaves was Ixora coccinea, followed by Ligustrum sinense. All other species had lower levels of it, but Viburnum prunifolium and Podocarpus macrophyllus showed the lowest contents (Table 5).

The species that showed the highest concentration of Mn was Dracaena marginata differing sharply from the other plants. Lower rate of this nutrient was found in Ixora coccinea, Podocarpus macrophyllus, Gardenia jasminoides and Murraya paniculata (Table 5). Gardenia and ixora usually show manganese deficiency symptoms (UNIVERSITY OF FLORIDA, 2013).

Viburnum prunifolium ansd Ligustrum sinense were the species with the highest concentration of $\mathrm{Zn}$ in their leaves and those that had lower leaf nutrient content was Rhapis excelsa, Podocarpus macrophyllus and Murraya paniculata (Table 5).

The total amount of nitrogen accumulated in the plant was higher in Podocarpus macrophyllus. The second group is composed of Rhapis excelsa. Then Ixora coccinea, Gardenia jasminoides, Ligustrum sinense, Murraya paniculata, and Dracaena marginata, and finally, other species (Table 6). Nitrogen fertilization increased the development and growth of the seedlings of Rhapis excelsa, raising dry weight production of shoots, leaf area, stalk diameter, number of leaves and plant height (LUZ et al., 2006). 
Table 6. Summary of the analysis of variance and total amount of macronutrients accumulated in ornamental plants.

\begin{tabular}{|c|c|c|c|c|c|c|}
\hline \multirow[b]{2}{*}{ Factor of variation } & \multicolumn{6}{|c|}{ Total amount of macronutrientes in ornamental plants } \\
\hline & $\mathbf{N}$ & $\mathbf{P}$ & $\mathbf{K}$ & $\mathbf{C a}$ & Mg & $\mathbf{S}$ \\
\hline & \multicolumn{6}{|c|}{ - Pr $>\mathrm{Fc}$ - } \\
\hline Species of ornamental plants & $<0.001$ & $<0.001$ & $<0.001$ & $<0.001$ & $<0.001$ & $<0.001$ \\
\hline CV \% & 31.58 & 35.94 & 41.72 & 33.93 & 28.35 & 24.22 \\
\hline Species of ornamental plants & \multicolumn{6}{|c|}{ - } \\
\hline Ixora coccinea & $2013 \mathrm{c}^{\mathrm{A}}$ & $305 \mathrm{~b}$ & $2579 \mathrm{a}$ & $811 \mathrm{~d}$ & $538 \mathrm{c}$ & $469 d$ \\
\hline Gardenia jasminoides & $1843 \mathrm{c}$ & $229 c$ & $1885 \mathrm{~b}$ & $1435 \mathrm{c}$ & $362 \mathrm{c}$ & $339 \mathrm{c}$ \\
\hline Rhapis excelsa & $3916 \mathrm{~b}$ & $431 \mathrm{a}$ & $4317 \mathrm{a}$ & $600 \mathrm{~d}$ & $337 \mathrm{c}$ & 682 a \\
\hline Podocarpus macrophyllus & 5268 a & $471 \mathrm{a}$ & 2943 a & $3635 \mathrm{~b}$ & $877 \mathrm{~b}$ & 790 a \\
\hline Ligustrum sinense & $2951 \mathrm{c}$ & $309 \mathrm{~b}$ & $1640 \mathrm{~b}$ & $892 \mathrm{~d}$ & $303 \mathrm{~d}$ & $409 \mathrm{c}$ \\
\hline Murraya paniculata & $2343 \mathrm{c}$ & $207 \mathrm{c}$ & $2643 \mathrm{a}$ & $2280 \mathrm{c}$ & $253 \mathrm{~d}$ & $409 \mathrm{c}$ \\
\hline Clusia fluminensis & $2527 \mathrm{c}$ & $325 \mathrm{~b}$ & $1776 \mathrm{~b}$ & $6251 \mathrm{a}$ & $1238 \mathrm{a}$ & $533 \mathrm{~b}$ \\
\hline Viburnum prunifolium & $845 d$ & $92 \mathrm{c}$ & $1060 \mathrm{~b}$ & $811 \mathrm{~d}$ & $182 \mathrm{~d}$ & $55 \mathrm{~d}$ \\
\hline Dracaena marginata & $2295 \mathrm{c}$ & $187 \mathrm{c}$ & $3284 \mathrm{a}$ & $1698 \mathrm{c}$ & $387 \mathrm{c}$ & $350 \mathrm{c}$ \\
\hline Dypsis lutescens & $810 \mathrm{a}$ & $83 \mathrm{a}$ & $931 \mathrm{a}$ & $514 \mathrm{a}$ & $158 \mathrm{a}$ & $109 \mathrm{a}$ \\
\hline
\end{tabular}

${ }^{\text {AT }}$ The averages followed by the same lower case letter do not differ among plant species by Scott-Knott test, at 5\% probability.

The highest total accumulated amounts of $\mathrm{P}$ have been found in Rhapis excelsa and Ligustrum sinense, while the lowest accumulated $\mathrm{P}$ content was in Dypsis lutescens (Table 6). It was observed for $\mathrm{P}$ that Viburnum prunifolium and Dracaena marginata have low levels of exportation but which have been grown in soil at high nutrient content and are acidic soils (Table 2), which can leave the nutrient not available.

The total accumulation of $\mathrm{K}$ was well balanced among the species. Rhapis excelsa, Dracaena marginata, Podocarpus macrophyllus, Murraya paniculata and Ixora coccinea were the species that most accumulated this element. Potassium deficiency is by far the most common deficiency of palms growing in production fields or landscapes throughout much of the world (BROSCHAT, 2009; 2014b). However, Dypsis lutescens and Viburnum prunifolium and were the plants that showed lowest accumulation of K (Table 6).

Clusia fluminensis was the specie with the highest accumulation of $\mathrm{Ca}$ drawing nearly ten times the Rhapis excelsa and almost double from seen in Podocarpus macrophyllus which is the second species that most drew $\mathrm{Ca}$ (Table 6). This big difference in $\mathrm{Ca}$ accumulation was due to higher amount of $\mathrm{Ca}$ in Clusia fluminensis leaves, because they are thick and succulent leaves, and $\mathrm{Ca}$ is a major component of the cell wall of its plants. In the leaves of Clusia obdeltifolia, we observed the presence of calcium oxalate crystals in the form of drusen distributed throughout the mesophyll (SILVA et al., 2014). In other species, the amount of $\mathrm{Ca}$ exported remained at similar levels.

The greatest amount of $\mathrm{Mg}$ was accumulated in Clusia fluminensis and Ixora coccinea, followed by Podocarpus macrophyllus. Viburnum prunifolium, Dypsis lutescens, Ligustrum sinense and Murraya paniculata were the plants with the lowest accumulation (Table 6).

Podocarpus macrophyllus and Rhapis excelsa accumulated the largest amounts of S, and Viburnum prunifolium was the specie with the lowest accumulation (Table 6).

When comparing the values with a standard culture, for example, a maize plant accumulates theoretically 83.0 $\mathrm{g}$ of dry matter; $788.9 \mathrm{mg}$ of $\mathrm{N} ; 137.5 \mathrm{mg} \mathrm{P} ; 1385.6 \mathrm{mg}$ of $\mathrm{K} ; 551.8 \mathrm{mg}$ of $\mathrm{Ca} ; 217.9 \mathrm{mg} \mathrm{Mg}$ and $92.5 \mathrm{mg}$ of $\mathrm{S}$ (CARVALHO et al., 2007). It is possible to observe a greater nutrient accumulation in ornamental, mainly because it has a fuller plant structure.

Viburnum prunifolium, Dracaena marginata and Dypsis lutescens were the species that accumulated the lowest amount of B in relation to others (Table 7). 
Table 7. Summary of the analysis of variance and total amount of micronutrients accumulated in ornamental plants.

\begin{tabular}{|c|c|c|c|c|c|}
\hline \multirow[b]{2}{*}{ Factor of variation } & \multicolumn{5}{|c|}{ Total amount of micronutrients in ornamental plants } \\
\hline & B & $\mathbf{F e}$ & $\mathbf{C u}$ & Mn & Zn \\
\hline & \multicolumn{5}{|c|}{ 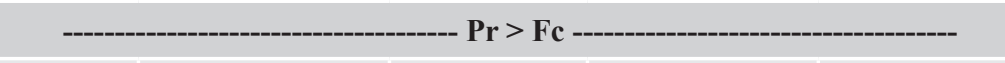 } \\
\hline Species of ornamental plants & $<0.001$ & 0.02 & $<0.001$ & $<0.001$ & $<0.001$ \\
\hline $\mathrm{CV} \%$ & 32.74 & 46.10 & 29.44 & 37.98 & 30.14 \\
\hline Species of ornamental plants & \multicolumn{5}{|c|}{-_- } \\
\hline Ixora coccinea & $7.25 \mathrm{a}^{\mathrm{A}}$ & $80.25 b$ & $2.05 \mathrm{c}$ & $3.10 \mathrm{c}$ & $4.80 \mathrm{~b}$ \\
\hline Gardenia jasminoides & $6.10 \mathrm{a}$ & $227.10 \mathrm{a}$ & $1.60 \mathrm{c}$ & $6.40 \mathrm{c}$ & $2.05 \mathrm{~b}$ \\
\hline Rhapis excelsa & $6.42 \mathrm{a}$ & $202.20 \mathrm{a}$ & $4.15 \mathrm{a}$ & $20.55 b$ & $7.55 \mathrm{a}$ \\
\hline Podocarpus macrophyllus & $7.27 \mathrm{a}$ & $225.02 \mathrm{a}$ & $2.50 \mathrm{~b}$ & $7.92 \mathrm{c}$ & $4.87 \mathrm{~b}$ \\
\hline Ligustrum sinense & $9.47 \mathrm{a}$ & $107.37 \mathrm{~b}$ & $3.02 \mathrm{~b}$ & $27.85 \mathrm{~b}$ & $8.30 \mathrm{a}$ \\
\hline Murraya paniculata & $5.97 \mathrm{a}$ & $185.40 \mathrm{a}$ & $1.55 \mathrm{c}$ & $11.05 \mathrm{c}$ & $3.15 \mathrm{~b}$ \\
\hline Clusia fluminensis & $7.55 \mathrm{a}$ & $237.27 \mathrm{a}$ & $3.12 \mathrm{~b}$ & $32.95 \mathrm{a}$ & $4.57 \mathrm{~b}$ \\
\hline Viburnum prunifolium & $3.25 \mathrm{~b}$ & $155.60 \mathrm{a}$ & $0.52 \mathrm{c}$ & $10.62 \mathrm{c}$ & $5.00 \mathrm{~b}$ \\
\hline Dracaena marginata & $4.47 \mathrm{~b}$ & $223.17 \mathrm{a}$ & $1.27 \mathrm{c}$ & $36.05 \mathrm{a}$ & $7.47 \mathrm{a}$ \\
\hline Dypsis lutescens & $2.55 \mathrm{a}$ & $73.05 \mathrm{a}$ & $1.07 \mathrm{a}$ & $8.30 \mathrm{a}$ & $3.57 \mathrm{a}$ \\
\hline
\end{tabular}

${ }^{A}$ The averages followed by the same lower case letter do not differ among plant species by Scott-Knott test, at 5\% probability.

Smaller amounts of Fe were accumulated by Ixora coccinea and Dypsis lutescens compared to other species. Due to contamination of the samples of roots, values are overestimated (Table 7).

Rhapis excelsa accumulated the highest total amount of Cu comparing to all other species. It is followed by Ligustrum sinense, Clusia fluminensis and Podocarpus macrophyllus (Table 7). Viburnum prunifolium and Dracaena marginata have low nutrient accumulation, but in its soil the level is high, which may indicate that the nutrient is not essential for the plant (Table 2). Among the micronutrients accumulated fewer in chrysanthemum was copper (MOTA et al., 2012).

The $\mathrm{Mn}$ greater accumulation was in Dracaena marginata and Clusia fluminensis. In the Clusia fluminensis maybe it is caused because of the high content in soil (Table 2) and mainly due to the accumulation on leaves (Table 5). Smaller accumulations were observed in the Ixora coccinea, Gardenia jasminoides, Podocarpus macrophyllus, Murraya paniculata, Viburnum prunifolium and Dypsis lutescens (Table 7).

The species with the highest total accumulation of Zn was also the Ligustrum sinense, Rhapis excelsa and in Dracaena marginata (Table 7). It is accepted that the root absorption of zinc actively give, being inhibited by copper and iron, while magnesium has greater inhibitory effect than calcium and zinc deficiency in classical literature induced phosphorus at high levels in both the middle and in solution (MALAVOLTA, 2006).

Ornamental plants that accumulated the highest amounts of N, P and K were Podocarpus macrophyllus and Rhapis excelsa (about 8.7 g NPK per pot), followed by Dracena marginata (5.8 g per pot). Ixora coccinea, Ligustrum sinense, and Murraya paniculata and Clusia fluminensis form another group that has accumulated around 4.6 to $5.2 \mathrm{~g} \mathrm{NPK}$ per pot, followed by Gardenia jasminoides which accumulated $4.0 \mathrm{~g}$ NPK per pot. The plants that accumulated the least amount of $\mathrm{N}, \mathrm{P}$ and $\mathrm{K}$ was Viburnum prunifolium and Dypsis lutescens with 1.8 to $2.0 \mathrm{~g}$ NPK per pot. This grouping can help producers as the dose of NPK fertilizer to be used in these groups of ornamental plants.

In addition to the dose of fertilizer, other important information for fertilization is the NPK ratio for the choice of fertilizer. Considering the average efficiency of nitrogen, phosphorus and potassium, in tropical soils, of 50, 20 and 70\% (MALAVOLTA, 2006), respectively, the studied ornamental plants can be grouped into the following NPK ratios: 2:1:2 - Viburnum prunifolium and Dypsis lutescens, Dracena marginata and Murraya paniculata; 2:1:1 - Podocarpus macrophyllus, Rhapis excelsa and Ligustrum sinense e 1: 1: 1 - Ixora coccinea, Gardenia jasminoides and Clusia fluminensis.

\section{CONCLUSION}

The accumulation of nutrients by ornamental plants is different among species and this information should be used to adjust fertilizer recommendations.

Ornamental plants were grouped as demand and NPK ratio, to assist in the management of fertilizer. 


\section{ACKNOWLEDGMENTS}

Thanks to the AFLOVAR (Ribeira Valley Flower and Plants Producers Association) for the donation of plants and financial assistance.

\section{REFERENCES}

ALVES, F.S.; JASMIM, J.M.; CARVALHO, A.J.C.; THIEBAUT, J.T.L. Qualidade e teores de nutrientes de palmeira-rápis em substrato com fibra de coco. Horticultura Brasileira, v.28, n.1, p.91-96. 2010.

BECKMANN-CAVALCANTE, M.Z.; PIVETTA, K.F.L.; CAVALCANTE, ÍTALO H.L.; CAVALCANTE, L.F.; BELLINGIERI, P.A.; CAMPOS, M.C.C. Condutividade elétrica da solução nutritiva para o cultivo do crisântemo em vaso. Revista Brasileira de Ciência do Solo, v.34. n.3, p.747-756, 2010.

BROSCHAT, T.K. Nutrition and Fertilization of Palms in Containers. (Univ. Florida, Environ. Hort. Dept. Circ. ENH1010), 2014. Available at: http://edis.ifas.ufl.edu/ pdffiles/EP/EP26200.pdf. Accessed on: 05 October 2016.

BROSCHAT, T.K. Magnesium deficiency in palms (Univ. Florida, Environ. Hort. Dept. Circ. ENH1014). Available at: http://edis.ifas.ufl.edu/EP266. Accessed on: 13 February 2016.

BROSCHAT, T.K. Nutrient deficiency symptons of woody ornamental plants in South Florida. ENH1098. Gainesville: Environmental Horticulture Department, UF/ IFAS Extension, 2008. 5p.

BROSCHAT, T.K. Palm Nutrition and Fertilization. HortTechnology, v.19, n.4, p. 690-694, 2009b.

CARVALHO, L.B.; BIANCO, S.; PITELLI, R.A.; BIANCO, M.S. Estudo comparativo do acúmulo de massa seca e macronutrientes por plantas de milho var. BR-106 e Brachiaria plantaginea. Planta Daninha, v.25, n.2, pp.293-301, 2007.

IBRAFLOR. O Mercado de Flores no Brasil. Available at: http://www.ibraflor.com/publicacoes/vw.php?cod=235. Accessed on: 23 july 2015.

JUNQUEIRA, A.H.; PEETZ, M.S. O futuro da floricultura no Brasil. Ibraflor Informativo, n.44, p.6, 2005.

LINS, S.R.O.; COELHO, R.S.B. Ocorrência de doenças em plantas ornamentais tropicais no Estado de Pernambuco. Fitopatologia Brasileira, v.29, p.332-335, 2004.
LUZ, P.B.; TAVARES, A.R.; PAIVA, P.D.O.; MASSOLI, L.A.L.; AGUIAR, F.F.A.; KANASHIRO, S.; STANCATO, G.C.; LANDGRAF, P.R.C. Efeitos de nitrogênio, fósforo e potássio no crescimento de Rhapis excelsa (Thunberg) Henry ex. Rehder (palmeira-ráfia). Ciência e Agrotecnologia, v.30, n.3, p.429-434, 2006.

MALAVOLTA, E. Manual de nutrição mineral de plantas. São Paulo: Ceres, 2006. 638p.

MALAVOLTA, F.; VITTI, G.C.; OLIVEIRA, S.A. Avaliação do estado nutricional das plantas. Princípios e aplicações. 2 ed. Piracicaba: POTAFOS, 1997. 319p.

RAIJ, B. van; ANDRADE, J.C.; CANTARELLA, H.; QUAGGIO, J.A. Análise química para avaliação da fertilidade de solos tropicais. Campinas: Instituto Agronômico, 2001. 285p.

SILVA, C.R.A.; LEITE, K.R.B.; FERREIRA, L.M.S.L.; SILVA, M.S.; SILVA, L.B. Influência da altitude na plasticidade foliar de Clusia obdeltifolia Bittrich (Clusiaceae). Revista Nordestina de Biologia, v.23, n.1, p.29-48, 2014.

TOMBOLATO, A.F.C.; CASTRO, C.E.F.; GRAZIANO, T.T.; MATHES, L.A.F.; FURLANI, A.M.C. Ornamentais e flores. In: RAIJ, B.; QUAGGIO, J.A.; CANTARELLA, H.; FURLANI, A.M.C. Recomendações de adubação e calagem para o estado de São Paulo. Campinas: Instituto Agronômico \& Fundação IAC. cap. 20 (Boletim Técnico $\left.\mathrm{n}^{\circ} 100\right), 1997$.

UCHIDA, R.S. 2000. Recommended plant tissue nutrient levels for some vegetable, fruit, and ornamental foliage and flowering plants in Hawaii. In: SILVA, J.A.; UCHIDA, R.S. (eds.), Plant nutrient management in Hawaii's soils. Manoa: College of Tropical Agriculture and Human Resources, 2000. p.57-65.

UNIVERSITY OF FLORIDA. Plant Nutrition Deficiency Database (NutDef). Available at: < hort.ifas.ufl.edu/nutdef. Accessed on: 05 October 2016.

VIEIRA, A.A; SAMPAIO, G.R; SAMPAIO, Y.S.B. Floricultura em Pernambuco: Perspectivas de crescimento para 2020. Available at: http://www.sober. org.br/palestra/5/1173.pdf. Accessed on: 25 July 2016.

WONG, M. Visual symptoms of plant nutrient deficiencies in nursery and landscape plants. Honolulu: University of Hawaii, 2005. 4p. (Soil and Crop Management; SCM-10). 